\title{
Correction: From micro- to macroevolution: insights from a Neotropical bromeliad with high population genetic structure adapted to rock outcrops
}

Mateus Ribeiro Mota • Fabio Pinheiro (D) - Barbara Simões dos Santos Leal • Carla Haisler Sardelli • Tânia Wendt • Clarisse Palma-Silva (iD

Published online: 27 August 2020

(c) The Author(s), under exclusive licence to The Genetics Society 2020

Correction to: Heredity

https://doi.org/10.1038/s41437-020-0342-8

The original version of this Article omitted the following from the Acknowledgements:
"The authors thank Espaço da Escrita - Pro-Reitoria de Pesquisa - UNICAMP - for the language services provided". This has now been corrected in both the PDF and HTML versions of the Article. 